\title{
MICROFACIES AND DEPOSITIONAL ANALYSIS OF THE MISHRIF FORMATION IN SELECTED WELLS OF RATAWI OILFIELD, SOUTHERN IRAQ
}

\author{
${ }^{1}$ Hussein A. Chafeet ${ }^{*}{ }^{2}$ Amna M. Handhal, ${ }^{3}$ Maysaa Kh. Raheem \\ ${ }^{1}$ Department of Oil and Gas Engineering, College of Oil and Gas Engineering, Basrah University for Oil and \\ Gas, Basrah, Iraq \\ ${ }^{2}$ Department of Geology, Collage of Science, University of Basrah, Basrah, Iraq \\ ${ }^{3}$ Basrah Oil Company, Ministry of Oil, Basrah, Iraq \\ *Email: hussein.aliwi@buog.edu.iq \\ Received: 3 March 2020; accepted: 24 June 2020
}

\begin{abstract}
This paper includes studying the distribution of microfacies, diagenetic processes and depositional basin of the Mishrif Formation in selected wells of Ratawi oilfield (Ratawi-2 and Ratawi-5), southern Iraq. More than 200 thin sections of samples were examined of the above-mentioned wells. The Mishrif Formation is divided into three major microfacies: lime mudstone, wackestone, and packstone, which are deposited in sub-basinal, lagoonal open shelf margin, and, shoal environments. Benthonic foraminifera, planktonic, Echinodermata and algae represent the fossils in the Mishrif Formation. Dolomite and calcite are the main minerals components of formation. Seven diagenetic processes were recognized in the Mishrif Formation, showed positive and destructive effects on the reservoir quality; dissolution and neomorphism (recrystallization) had highly positive effects through creating and improving porosity and permeability, which led to improving reservoir quality. Cementation, micritization, and compaction have destructive effects, through reducing porosity and permeability and led to reducing reservoir quality. Other processes such as, dolomitization, authigenic minerals (pyrite) did not have strong effects on reservoir quality. Based on the genetic classification of the porosity, most of the porosity within the Mishrif Formation in this field was formed by diagenesis processes, in which the predominant pore types are vuggy, intraparticle, fractured, and moldic. Analysis of microfacies showed that there are three main facies and eight secondary facies in the Mishrif Formation. The longitudinal section of the depositional environments showed, that Mishrif Formation deposited in the sub-basinal, lagoonal, open shelf margin, and shoal environments depending on fossils observed in a number of microfacies.
\end{abstract}

Keywords: Microfacies; Formation; Diagenesis Process; Ratawi Oilfield 


\section{INTRODUCTION}

The Cretaceous rocks occupy a distinct position within the stratigraphic column in southern Iraq, where the content of this era represents good oil potential rocks. Some of these formations were considered as source rocks, while the others were reservoirs with high oil potentiality (Idan et al., 2020). The Mishrif Formation contains up to $40 \%$ of Cretaceous oil reserves in Iraq, and approximately $30 \%$ of the total Iraqi oil reserves (Mohammed et al., 2020). The Mishrif Formation (Cenomanian - Early Turonian age) is a super-giant reservoir in Iraq and the adjacent countries (Alsharhan, 1995 and Aqrawi et al., 1998). Oil reserves of the formation account for $40 \%$ of the Cretaceous oil reserve and approximately $30 \%$ of Iraq's confirmed reserves (Aqrawi et al., 1998). The microfacies is described as completely sedimentological and paleontological records which can be defined and categorized from thin sections, peels, polished slabs, or rock samples (Flügel, 2010). For the importance of the determination, the relationship between the microfacies and the diagenesis processes, the depositional environments and their effect on reservoir properties, this research is discussed, the microfacies through the examination thin sections via microscope and related to the diagenesis and depositional environments, and their effect on reservoir facies. The facies are also described following the idea of standard facies zones (Wilson, 1975), that describes a rimmed carbonate platform (Flügel, 2010). While Kendall (2007) defines facies as representing histological, structural, and synthetically properties that result from deposition processes and caused modification and accumulation within the depositional environment. Carbonate sediments and rocks are characterized by a broad range of physical properties which are affected by variable deposition and diagenesis processes (AlBaldawi, 2020). Lithofacies are determined based on depositional rock properties such as texture, constituent components, and sedimentary structures (Ahr, 2008). The classification of Dunham (1962) is an easy and widely applied classification for microfacies. Many geological studies have been done on the Mishrif Formation. The stratigraphic, depositional environment and facies studies were given by recognized four general facies within the Mishrif: restricted shelf, rudist build-up, open shelf and sub-basinal. Aqrawi et al. (1998) recognized two thirdorder sequences separated by an intra-formational unconformity which is recorded near the Iranian border at Amara. Al-Mimar et al. (2018) distinguish four facies associations in the studied succession, which include shallow open marine, shoal, deep marine, and basinal association. The stratigraphic succession was generally divided into eleven zones based on the gamma ray and geochemical data. Four facies associations were distinguished by Abbas et al. 
(2020,) each of which represents a distinct depositional environment and includes several microfacies, and these are Shallow open marine, Shoal, Back-Shoal, and Restricted marine. Mahdi (2004) studied the sequence stratigraphy and reservoir characterization of the Mishrif Formation, this study implied high-resolution sequence stratigraphic model, that relies on a time-based correlation scheme of deposition. Sadooni (2005) studied build-ups locations some distance away from the main platform margin, he considered that the maximum thickness of the Mishrif Formation in the Dujaila area was controlled by a local uplift the "Dujaila Shoal". Al-Mohammad (2012) recognized that a diagenetic processes affected on Mishrif microfacies in Tuba oilfield that has both early and late phases and the most effective processes are dissolution and dolomitization that contributed to the forming of porosity and also they have made significant enhancement in the quality of the Mishrif reservoir rocks, especially the shoal and the open marine facies. Al-Rawi et al.; (2015) studied the reservoir geological model and show that Tuba field is an anticline fold which its extension is in (north northwest), (south- southeast) direction and proved that facies model distribution completely matches the facies description in the study. Al-Ali et al.; (2019) pointed that the Mishrif Formation in the North Rumaila oilfield as represents as a carbonate platform ramp system, with scattered patch reefs and shoals developed across the ramp margin and the platform top and can be identified and build the sedimentary model with microfacies which apply to the Mishrif Formation. Al-Musawi et al. (2019) studied the facies of Mishrif Formation in Ratawi oilfield by the analysis of seven wireline logs and according to reservoir properties, effective porosity, permeability, and water saturation, the Mishrif Formation is divided into two main units, the upper $(\mathrm{mA})$ and the lower $(\mathrm{mB})$, separated by a shale member. The aim of this research is to study the distribution of microfacies, depositional environment and diagenesis processes of the Mishrif Formation at two wells in Ratawi oilfield by petrographic analysis to recognized and classify microfacies and spotlight the depositional environments.

\section{STUDY AREA}

Ratawi oilfield is located in the northwest of Basrah city, south of Iraq between latitudes (E705000.4 - 696000.36 m) and (N3394000.183 - 3373000.8 m) (Fig. 1). Ratawi oilfield is a structural dome with NS dominant direction and approximately $2 \mathrm{~km}$ length (Fig. 2). It contains prominent N-S trending structures, which their amplitudes increase with depth and reach $300 \mathrm{~m}$ at lower Cretaceous level. The most prominent narrow shorter antiforms include Ratawi structure (Jassim and Goff, 2006). 


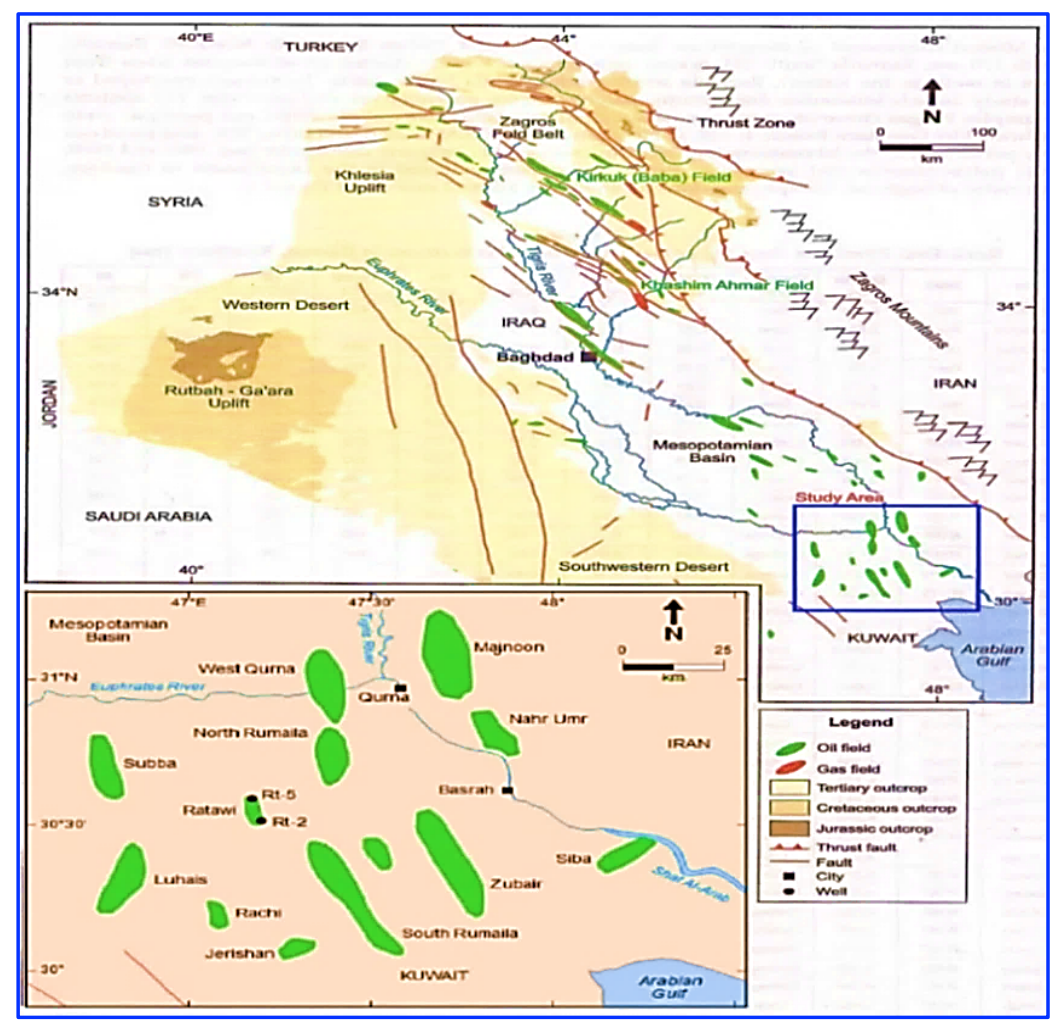

Fig. 1. Map of the study area (After Al-Ameri et al., 2009)

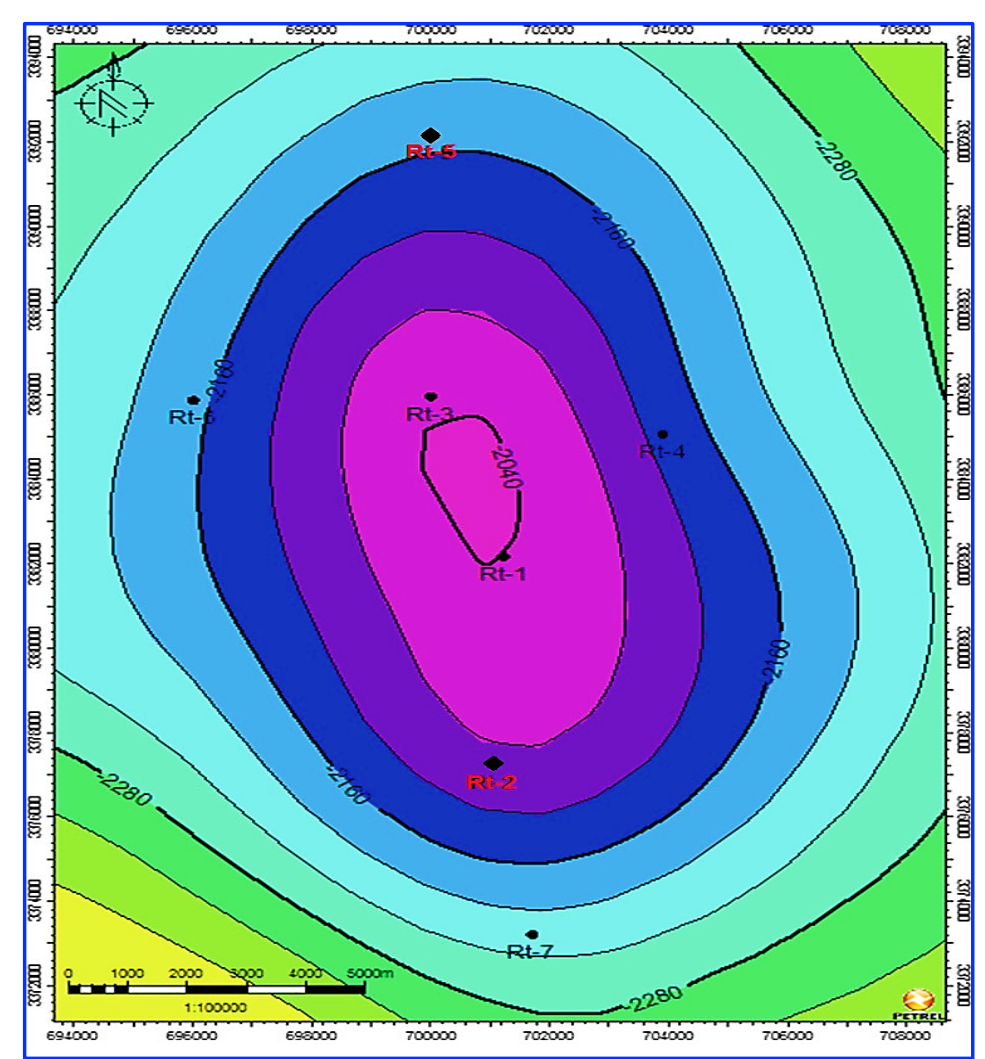

Fig. 2. Structural map on the top of Mishrif Formation in the Ratawi Oilfield (After AlMusawi et al., 2019) 


\section{STRATIGRAPHIC SETTING}

The Mishrif and the underlying the Rumaila Formation have been initially defined at Zubair oilfield in south of Iraq in well Zubair-3. The contact between the Mishrif and the Rumaila formations is gradational; however, the contact between the Mishrif and the overlying Kifil Formation is gradational too. Nevertheless, in many oilfields, south of Iraq, for instance the West Qurna oilfield, the Mishrif Formation is unconformable overlain by using the Khasib Formation in which the Kifil Formation is absent (Aqrawi, 1995). A cross section shows the divisions of the Mishrif Formation, the shale to carbonate ratio, the oil and water content in the Ratawi oilfield is summarized in Fig. 3 (Al-Musawi et al., 2019).

The Mishrif Formation is a heterogeneous that is organic limestone with a group of algae, rudist and coral reef limestone (Bellen et al., 1959). In its common region, this formation comprises grey white, dense, algal limestone with shell fragments and gastropods at the top and of brown, porous, detrital in part very shelly and rudist particles and foraminiferal limestone at the lowest. The formation obtains the high thickness $(270 \mathrm{~m})$ in the Zubair and Rumaila oilfields. Inside the Majnoon and Nahr Umr oilfields and along the Iraq-Iran borders, its maximum thickness is $435 \mathrm{~m}$, however, the thickness of formation is $380 \mathrm{~m}$ in the Abu Amud field between Amara and Kut (south of Iraq). Thickness of the formation in the studied wells is $128 \mathrm{~m}$ in the Rt-2 and $137 \mathrm{~m}$ in Rt-5 well (Table 1). The Mishrif Formation in Ratawi oilfield is divided into three rocks units: Upper, Middle and Lower Mishrif (Basrah Central Labs, 1974) (Table 1) according to the facies distribution of the limestone rocks.

Table 1. Tops of the Mishrif Formation reservoir units in Ratawi oilfield

\begin{tabular}{|c|c|c|c|c|c|c|c|c|c|c|c|c|c|}
\hline \multirow[b]{2}{*}{ Well } & \multicolumn{3}{|c|}{ Mishrif Formation } & \multicolumn{3}{|c|}{ Upper Mishrif } & \multicolumn{3}{|c|}{ Middle Mishrif } & \multicolumn{3}{|c|}{ Lower Mishrif } & \multirow[b]{2}{*}{$\begin{array}{l}\text { Rumaila } \\
\text { Formation }\end{array}$} \\
\hline & 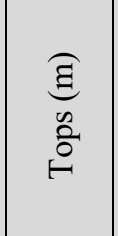 & 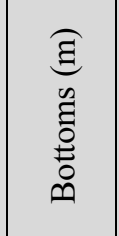 & 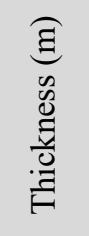 & 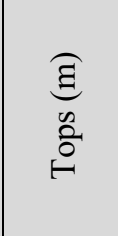 & 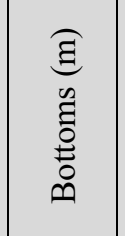 & 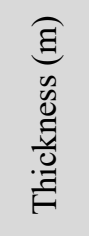 & 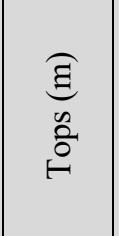 & $\begin{array}{l}\widehat{\Xi} \\
\tilde{E} \\
\tilde{0} \\
\tilde{0} \\
0\end{array}$ & 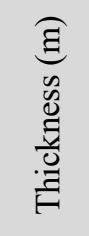 & $\begin{array}{l}\underset{\Xi}{\Xi} \\
\stackrel{0}{0} \\
\stackrel{0}{0}\end{array}$ & 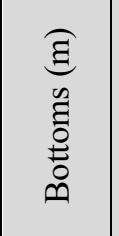 & 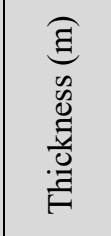 & \\
\hline Rt-2 & 2138.8 & 2266.8 & 128 & 2138.8 & 2158 & 19.5 & 2158 & 2212 & 54 & 2212 & 2266.5 & 54.85 & 2266.8 \\
\hline Rt-5 & 2203.7 & 2340.7 & 137 & 2203.7 & 2214.7 & 11 & 2214.7 & 2284 & 69.3 & 2284 & 2340.7 & 56.7 & 2340.7 \\
\hline
\end{tabular}




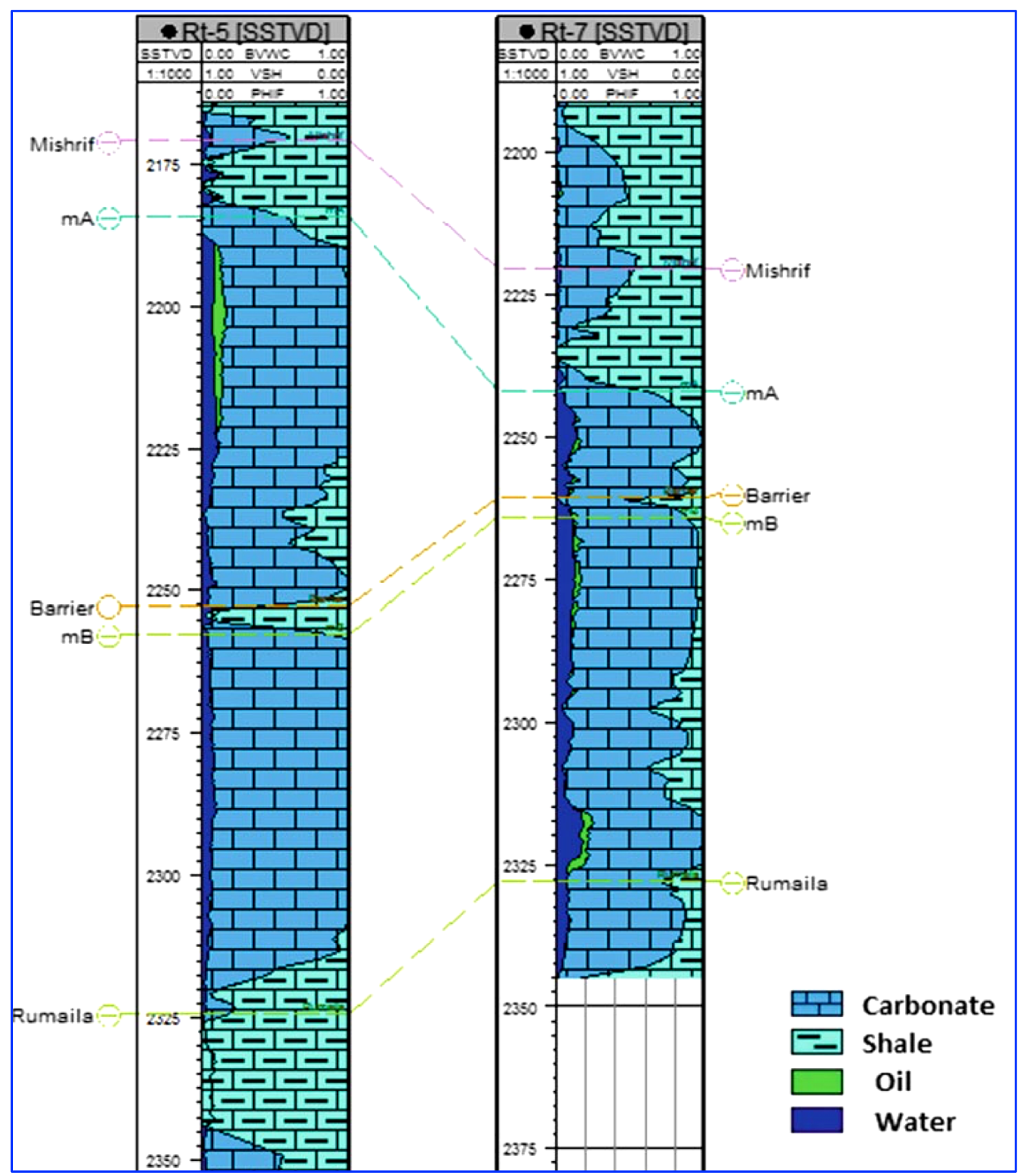

Fig. 3. N-S Cross section between the wells Rt-5 and Rt-7 shows divisions of the Mishrif Formation, the Shale to Carbonate ratio, and the oil and water content (After AlMusawi et al., 2019) 


\section{METHODOLOGY}

In this study, more than 200 thin sections of samples for the current study were based mainly on the Dunham (1962) classification by using a polarizing microscope to determine the texture, microfacies and identify the components and diagenesis processes. All thin sections were oriented and stained with Alizarin Red Solution (ARS) in order to detect calcite and dolomite (Dickson, 1966). Well-preserved digital photomicrographs of grains and structures such as stylolites were taken through a digital camera connected to the microscope and a computer program. To interpret and classify microfacies, the Flügel method (Flügel, 2004) was used. This step involves collecting and studying resources, mapping of study wells and choosing two wells from the Ratawi oilfield.

\section{RESULTS AND DISCUSSION}

\section{Microfacies Analysis}

Based on the relationship between fossil content and groundmass type, each of the main microfacies is subdivided into several submicrofacies. There are four microfacies, which recognized in the present study, as followed:

\section{Lime mudstone microfacies}

Lime mudstone was defined by Dunham (1962) as a kind of limestone that its infrastructure composed of microcrystalline calcite, which corresponds to the term micrite that was launched by Folk (1965). Micrite composed more than $90 \%$ of these microfacies, and it also consists of Allochems by ratios ranging from $2-10 \%$ and represented by bioclasts or lithoclasts, such kind of facies deposited in low energy environments (Bathurst, 1975). According to microfacies composition, is further specified:

1.1 Unfossiliferous lime mudstone submicrofacies

This submicrofacies is found only in upper Mishrif at well Rt-2 (Plates 1a and 1b), (Table 2) and (Figs. 4 and 6). Generally, the term of mudstone (micrite) refers to the quiet environment (Dunham, 1962). In addition to lime mudstone contributes to preventing living beings to gather and forming grains its inside. These microfacies is found within the micritic matrix. The most important digenesis processes that affected this microfacies are neomorphism. These facies could be compared with standard microfacies SMF 19, 23 that was deposited in facies zone FZ-8, 9 according to Wilson (1975) and Flügel (1982 and 2004), which represents the restricted lagoonal environment. 


\subsection{Bioclastic lime mudstone submicrofacies}

This microfacies is distinguished by using a rate of fossiliferous no longer exceed $(10 \%)$ consisting of Echinoderm and algae as well. This submicrofacies is observed in upper, middle and lower Mishrif in wells Ratawi-2 and Ratawi-5 (Plates 1c, 1d, 1e, and 1f), (Tables 2 and 3), and (Figs. 4 and 6). The most important digenesis processes that affected on this microfacies are compaction and dolomitization. This submicrofacies correlates the standard microfacies SMF-19 that was deposited in facies zone FZ-8 according to model of Wilson (1975) and Flügel (1982 and 2004), which represents restricted lagoonal environment.

\section{Wackestone microfacies}

This microfacies type, the percentage of skeletal and non-skeletal grains range is $10-40 \%$ of this microfacies. It is considered as the main common microfacies of the Mishrif Formation within the wells Rt-2 and Rt-5. This microfacies in skeletal grains, mainly composed of benthic foraminifera, mollusca shells, echinodermata and algae, which their structures have been observed intact and their parts are clear, buried in the micrite matrix (Dunham, 1962). While non-skeletal grains are represented by peloidal grains and bioclasts. This microfacies was subjected to a range of diagenesis processes including cementation, which were represented by several types such as blocky, granular mosaic cement, dolomitization that had partial effect and appearance of small dolomite crystals without facets, compaction, dissolution and micritization. Depending on the ratio of dominant grains and diagenetic processes, the wakestones are further divided into three sub microfacies, as followed:

2.1 Bioclastic wackestone submicrofacies

This microfacies has consists of microbioclast within varying levels, such as fragments and debris of planktonic (Hedbergella), algae, peloids with few ratios of both benthic foraminifera (Valvulinid and Pryozoa). The most important digenesis processes which are found in this submicrofacies are dolomitization, neomorphism, recrystallization, cementation, and the appearance of granular and blocky mosaic cement and characterized by the interparticle and intrapaticle porosity. This submicrofacies was abundantly observed in upper and lower Mishrif in wells Rt-2 and Rt-5 (Plates 2a, 2b, 2c, 2d, 2e, 2f, 3a, 3b, and 3c), (Tables 2 and 3), and (Figs. 4 and 6). It is also has been observed that there are stylolite solutions associated with the dolomite and pyrite. This microfacies is similar in characteristics with SMF-18 that was deposited in FZ-7, 8 according to model of Wilson (1975) and Flügel (1982 and 2004), which represents restricted lagoonal and open shelf margin environments. 


\subsection{Peloidal wackestone submicrofacies}

This submicrofacies consists of peloids of different sizes and shapes. It is soluble filled with more than one type of cement, fragments of benthic foraminifera such as (Miliolidae). The most important digenesis processes that affected this submicrofacies are the dissolution and micritization through the appearance of blocky mosaic cement and characterized by the vuggy porosity. This submicrofacies was found in Rt-2 and Rt-5 wells (Plates 3d, 3e, and 3f), (Tables 2 and 3) and (Figs. 4 and 6). It is also has been observed that there are stylolite solutions associated with the dolomite and pyrite. This facies could be compared with standard microfacies SMF-18 that was deposited in facies zone FZ-8 according to Wilson (1975) and Flügel (1982 and 2004), which represents lagoonal environment.

\section{Packstone microfacies}

This microfacies consist mainly of grains, which represent a ratio between $40-90 \%$ when it comparing with the micritic matrix which, it is partially or totally converted into micro and pseudosparite, in addition to the presence of fragments or different bioclast debris such as benthic foraminifera with few proportions including peloids. While the appearance of dolomite of various sizes and shapes in dolomitization process. The main packstone is further subdivided into four submicrofacies:

3.1 Bioclastic packstone submicrofacies

This microfacies is distinguished by using the presence of bioclast represented by algae, coral, mollusca, benthic foraminiferous fragments and debris. (Valvulinids, Nezzazata, Cisalveolina, Cycledomia and Rotalide), planktonic (Textularia), peloids with few ratios of both rudist and Echinoids. This submicrofacies is found in wells Rt-2 and Rt-5 (Plates 4a, 4b, 4c, 4d, 4e, 4f, and 5a), (Tables 2 and 3), and (Figs. 4 and 6). The most important digenesis processes, which are observed in this microfacies are dolomitization, micritization and cementation, the appearance of blocky mosaic, drusy mosaic and granular cement, also characterized by the intraparticle, vuggy, interparticle and moldic porosity. Stylolite solutions associated with the dolomite and pyrite were also recognized. This microfacies correlates with standard microfacies SMF-4 that is deposited in facies zones FZ-4 according to model Wilson (1975) and Flügel (1982 and 2004), which represents the reef slope environment.

3.2 Peloidal and bioclastic packstone submicrofacies

This submicrofacies is found in wells Rt-2 and Rt-5 (Plates 5b and 5c), (Tables 2 and 3), and (Figs. 4 and 6). This submicrofacies contains fragments of benthic foraminiferous with the micritic matrix partially converted into microsparite and increase the intraclasts grains represented by peloids and Miliolidae. The most important digenesis processes that affected 
this microfacies are the dissolution, micritization and recrystallization which represented by the interparticles, intercrystallines and moldic porosity. In addition to stylolite solutions. This microfacies represents deposition in the restricted lagoonal and open shelf margin environments as compared with the SMF-16 that is deposited in facies zone FZ-7, 8 according to model of Wilson (1975) and Flügel (1982 and 2004).

3.3 Benthonic foraminiferal and peloidal packstone submicrofacies

This submicrofacies is mainly formed from peliods and various sizes of benthic foraminifera (Valvulinids, Textularia and Cisalveolina), the presence of bioclasts debris represented by fragments and debris of algae, Miliolidae, and oolitic as well as presence staining oil that are located in micritic matrix. The peloids are generally represented by the difficulty of the determination of its origin, therefore it is formed with skeletal grains are represented by benthic foraminifera exposed to the micritization process or formed from non-skeletal grains such as incomplete pseudo-oolites that having no appropriate conditions for being complete also such facies are exposed to the cementation process. The main recognized digenesis process in this microfacies are the dissolution micritization, compaction and cementation (blocky mosaic, drusy mosaic and granular cement), which characterized by the vuggy, moldic and fractured porosity. This submicrofacies is found in wells Rt-2 and Rt-5 (Plates $5 \mathrm{~d}$, 5e, 5f, 6a, 6b, and 6c), (Tables 2 and 3), and) Figs. 4 and 6). It is also has been observed that there are stylolite solutions associated with the dolomite (Flügel, 2004). These facies could be compared with standard microfacies SMF-18 that was deposited in facies zone FZ-7, 8 according to Wilson (1975) and Flügel (1982 and 2004), which represents the lagoonal, shoal, and open shelf margin environments.

3.4 Planktonic foraminiferal packstone submicrofacies

Skeletal grains were the main components of this facies in proportion up to about $80 \%$ of the grains, and principally consists of abundant planktonic foraminifera such as Oligostegina, Globotruncana, Hedbergella, and Heterohelix) These assemblages are associated with limited number of rudist fragments, bioclasts, and a few ratios of benthonic foraminifera. This submicrofacies is observed in wells Rt-2 and Rt-5 (Plates 6d, 6e, and 6f), (Tables 2 and 3) and (Figs. 4 and 6). Compaction, dissolution, micritization and cementation are the main diagenetic processes in these facies, it observed by micrite which granular cement and characterized by the vuggy, interparticles and moldic porosity. This facies could be compared with standard microfacies SMF-3 that was deposited in facies zone FZ-3 according to model Wilson (1975) and Flügel (1982 and 2004), which represents the sub-basinal environment 
Table 2. Petrographic description, distribution of microfacies and diagenesis for the Mishrif Formation at well (Ratawi-2)

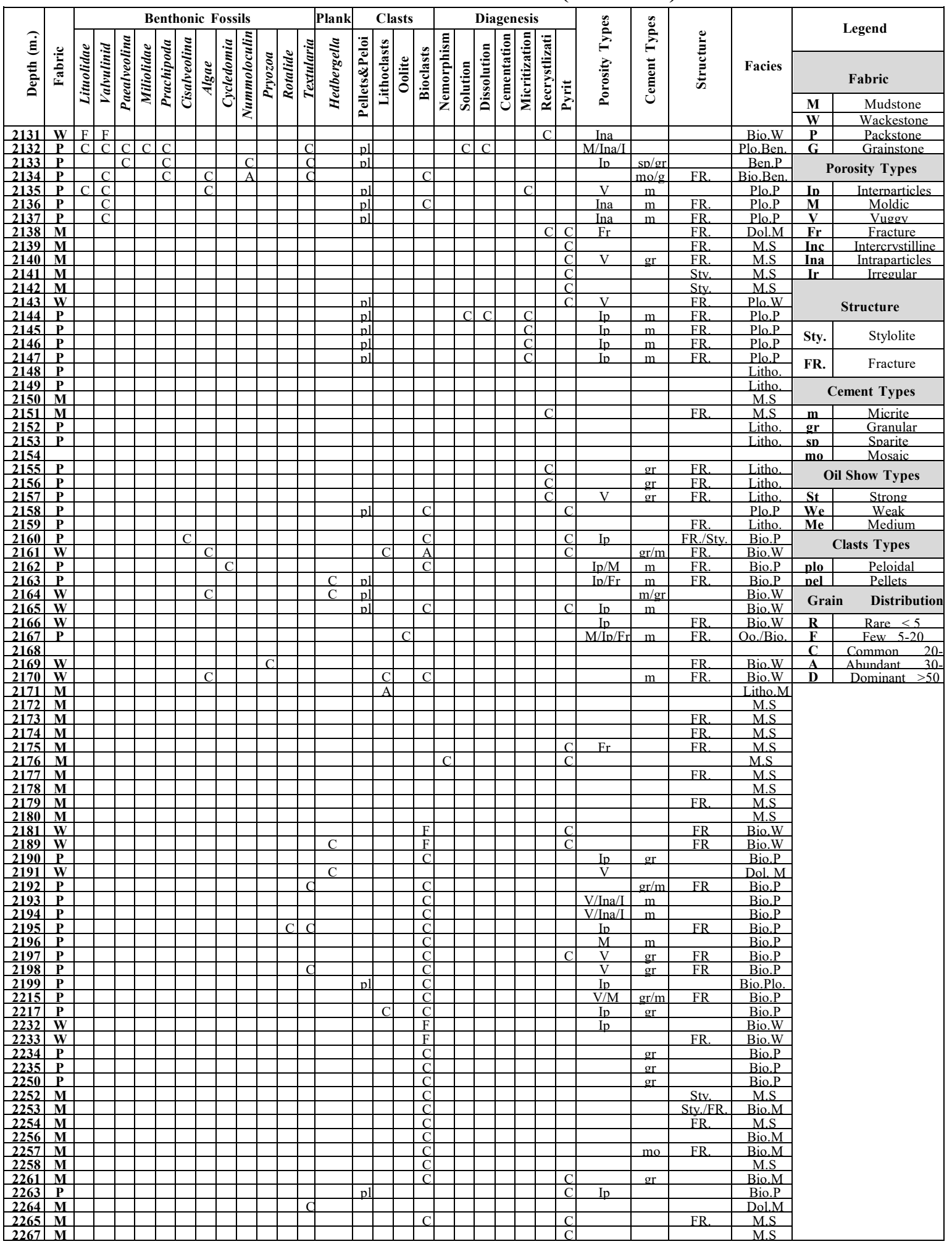


Table 3. Petrographic description, distribution of microfacies and diagenesis for the Mishrif Formation at well (Ratawi-5)

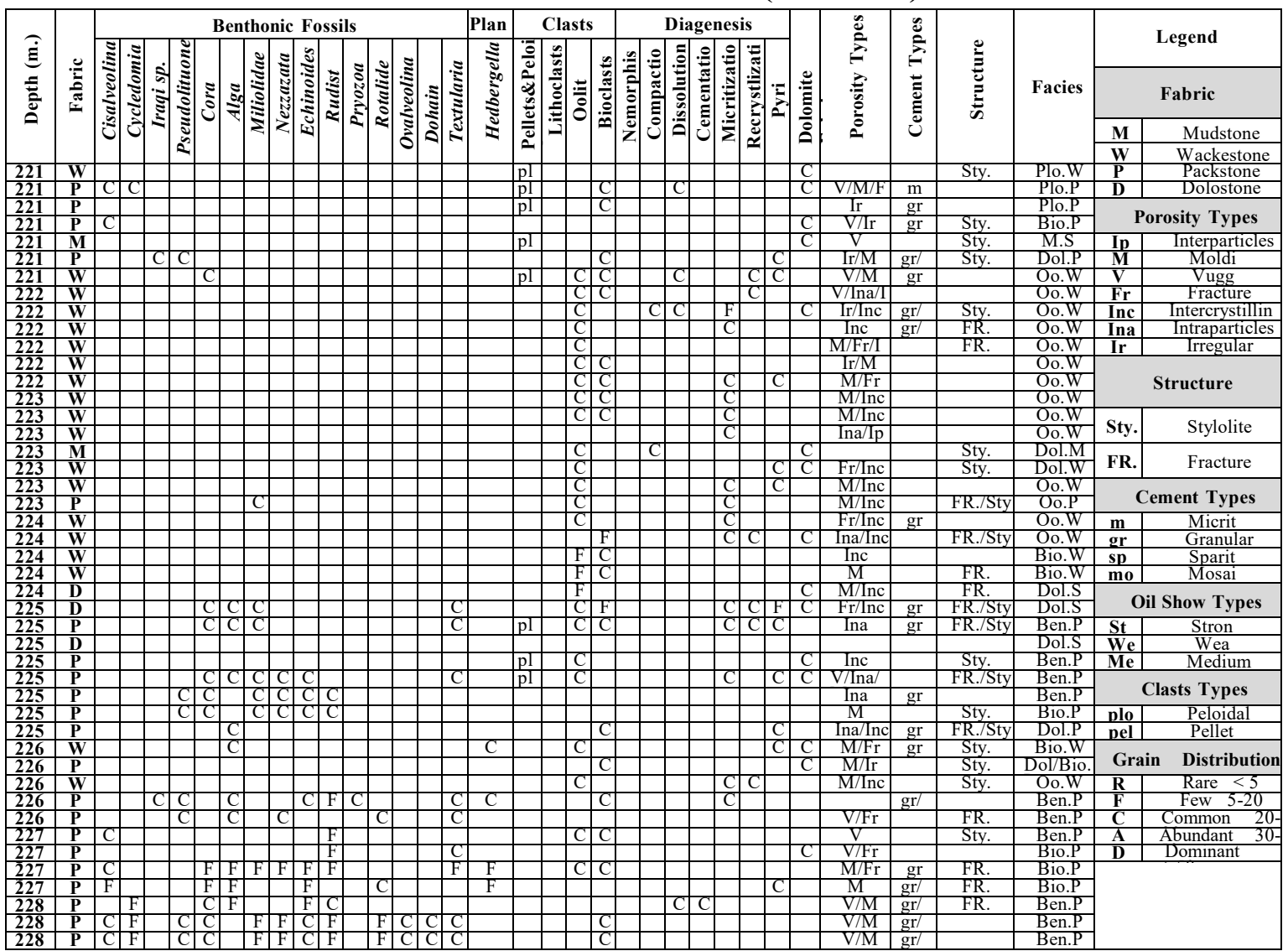

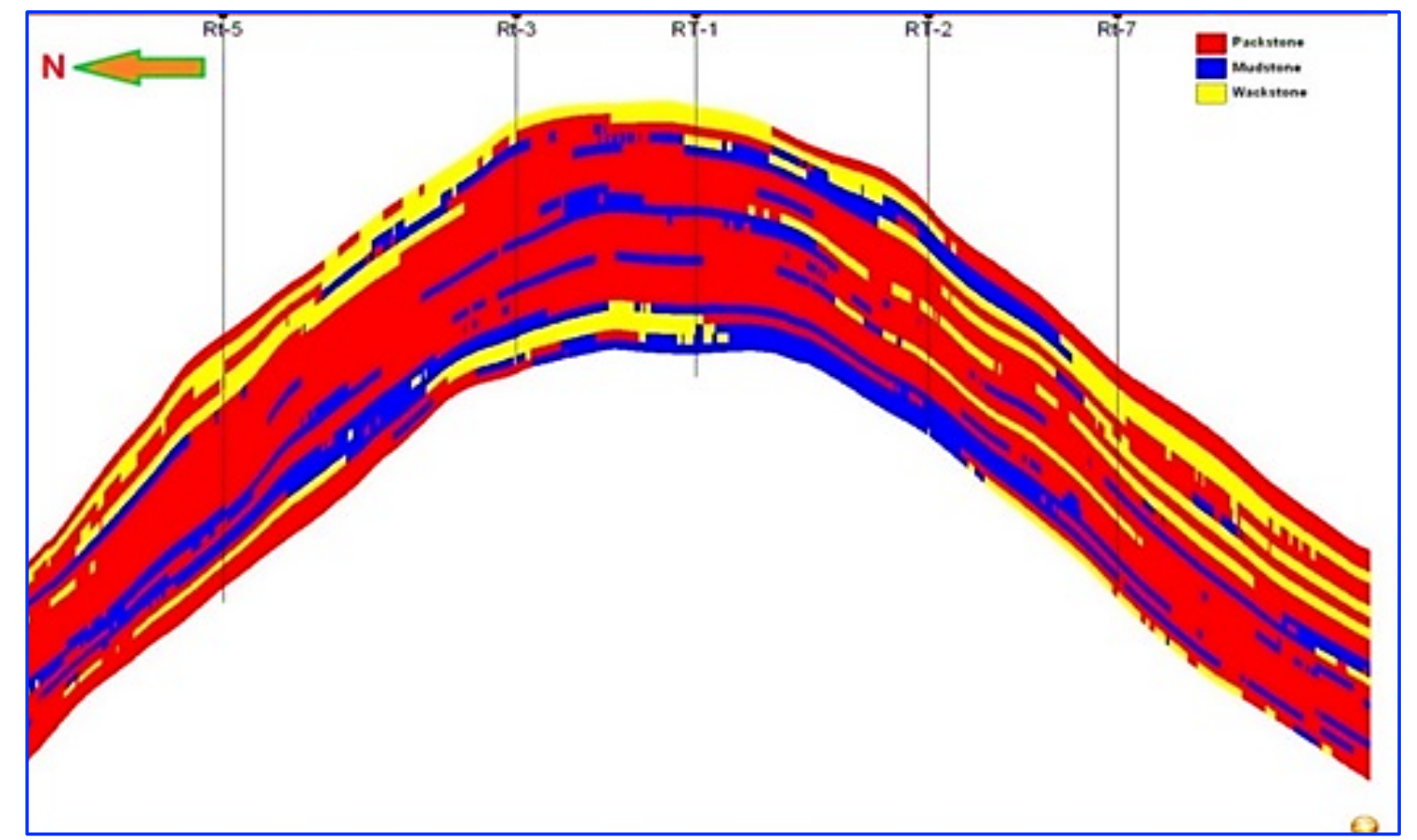

Fig. 4. Longitudinal-section of the microfacies of the studied wells in the Ratawi oilfield 


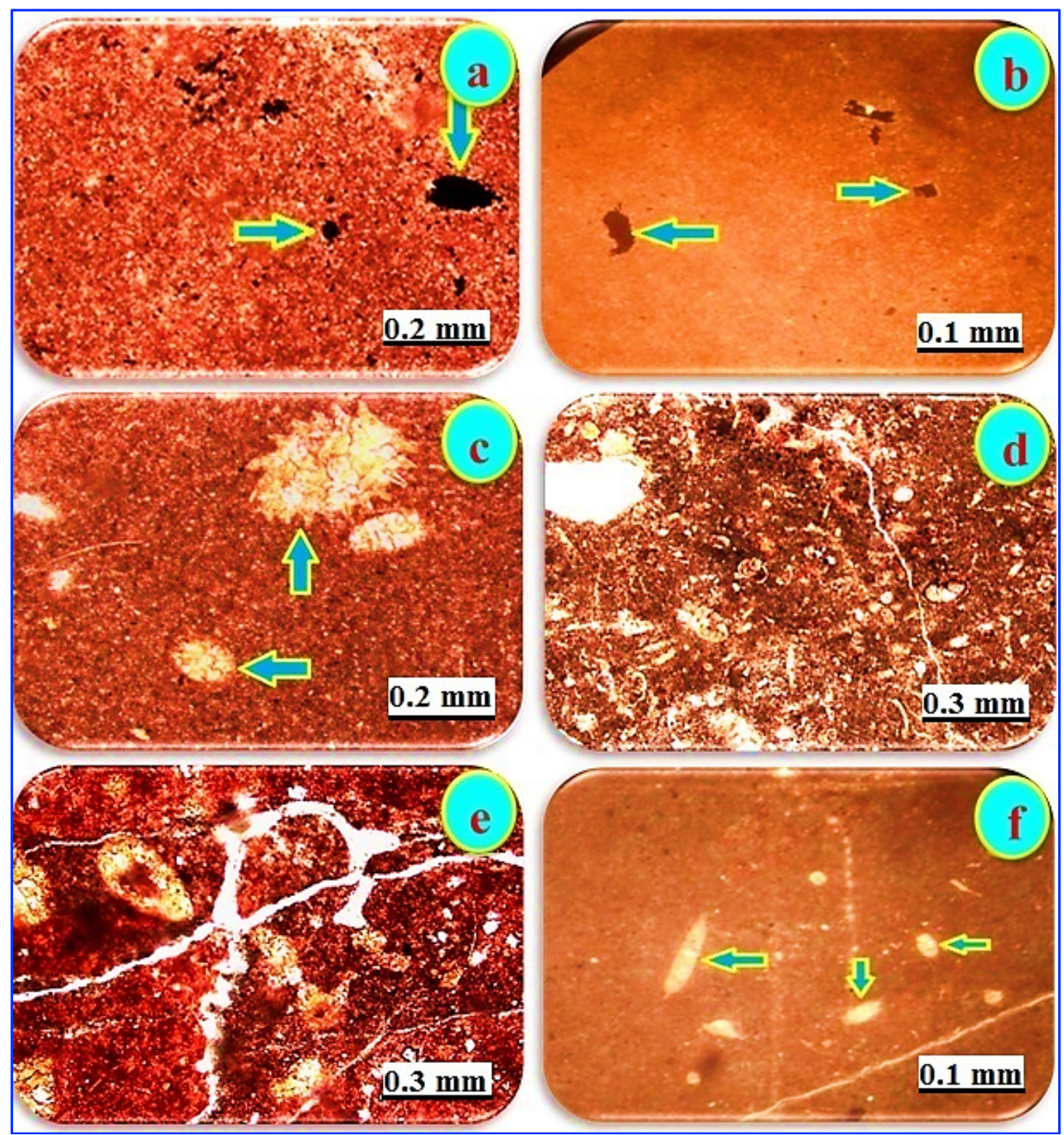

Plate 1. Photomicrographs showing: a) Unfossiliferous lime mudstone submicrofacies, and also appearance authigenic minerals, Rt-2, depth $2171 \mathrm{~m}$., b) Unfossiliferous lime mudstone submicrofacies, and characterized by found authigenic minerals, Rt-2, depth $2175 \mathrm{~m}$., c) Peloids within Bioclastic lime mudstone submicrofacies, as well as found interparticle porosity, Rt-2, depth $2165 \mathrm{~m}$., d) and algae within Bioclastic lime mudstone submicrofacies, and characterized by vuggy porosity and granular cement, Rt-2, depth 2139m., e) Bioclastic lime mudstone submicrofacies, as well as found recrystallization,

fractured porosity and pyrite, Rt-2, depth $2138 \mathrm{~m}$., f) Echinoderm and benthic foraminiferal within Bioclastic wackestone submicrofacies, and also presence granular cement, Rt-2, depth $2167 \mathrm{~m}$ 


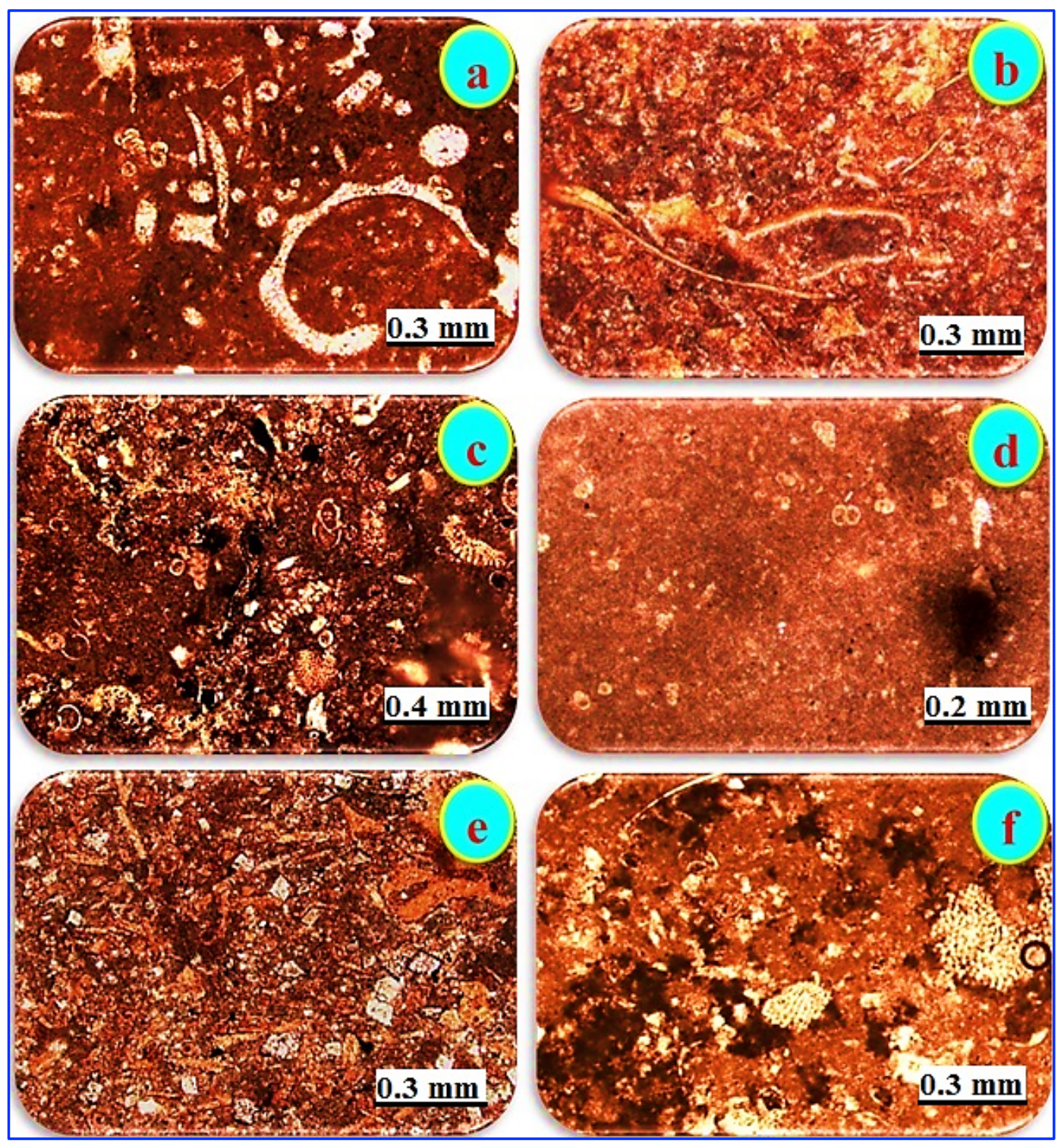

Plate 2. Photomicrographs showing: a) Bioclastic wackestone submicrofacies, and also appearance granular cement and pyrite, Rt-2, depth 2261m., b) Algae and lithoclasts within Bioclastic wackestone submicrofacies, and also presence granular and micrite cement and pyrite, Rt-2, depth $2161 \mathrm{~m}$., c) Bioclastic wackestone submicrofacies, and

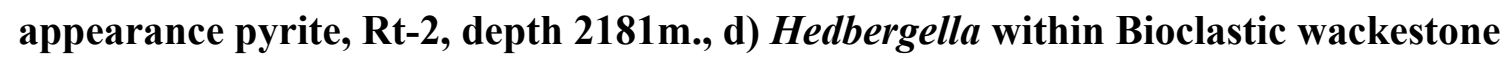
submicrofacies, and characterized by blocky mosaic cement, Rt-2, depth $2189 \mathrm{~m}$., e) Hedbergella within Bioclastic wackestone submicrofacies, and characterized by vuggy

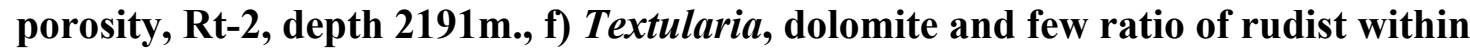
Bioclastic packstone submicrofacies, and also appearance vuggy and fractured porosity, Rt-5, depth 2272m 


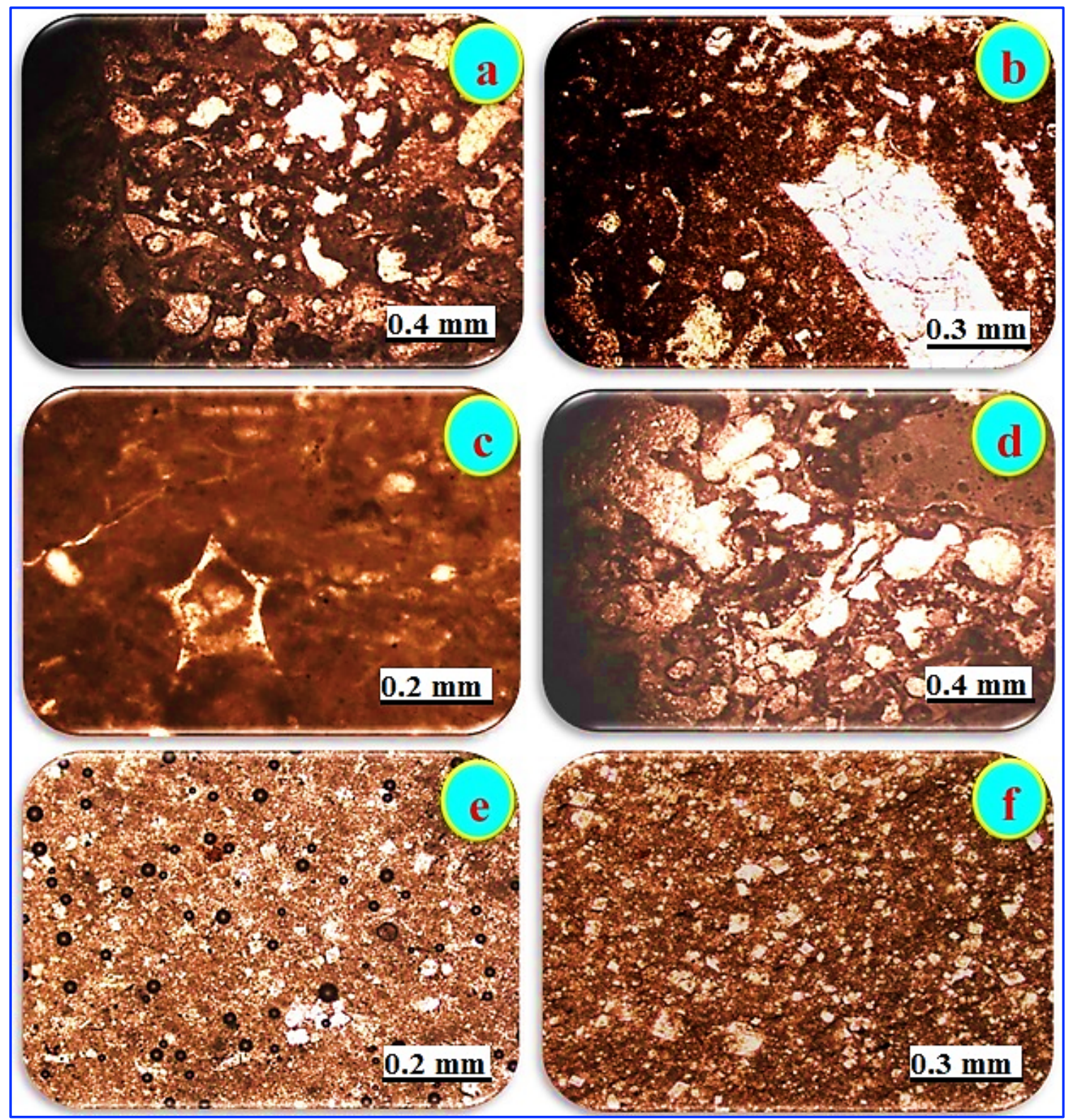

Plate 3. Photomicrographs showing: a) Peloidal wackestone submicrofacies, and characterized by vuggy porosity and pyrite, Rt-2, depth $2143 \mathrm{~m}$., b) Benthic foraminifera (Miliolidae and Nezzazata), algae, coral, Echinoderm and rudist fragments within Bioclastic lime mudstone submicrofacies, and characterized by moldic porosity and stylolite, Rt-5, depth $2257 \mathrm{~m}$., c) Hedbergella, and algae within Bioclastic wackestone submicrofacies, and characterized by moldic and fractured porosity, granular cement, stylolite, dolomite and pyrite, Rt-5, depth $2261 \mathrm{~m}$., d) Peloidal wackestone submicrofacies, and the solution channels, Rt-5, depth 2213m., e) Bioclasts and coral within Peloidal wackestone submicrofacies, as well as found recrystallization and dissolution process and presence of granular cement, vuggy and moldic porosity and pyrite, Rt-5, depth 2219m., f) Stylolite and medium oil shows within Peloidal wackestone submicrofacies, as well as found micritization, dissolution and compaction, and characterized by intercrystalline porosity and granular and micrite cement, Rt-5, depth $2224 \mathrm{~m}$. 


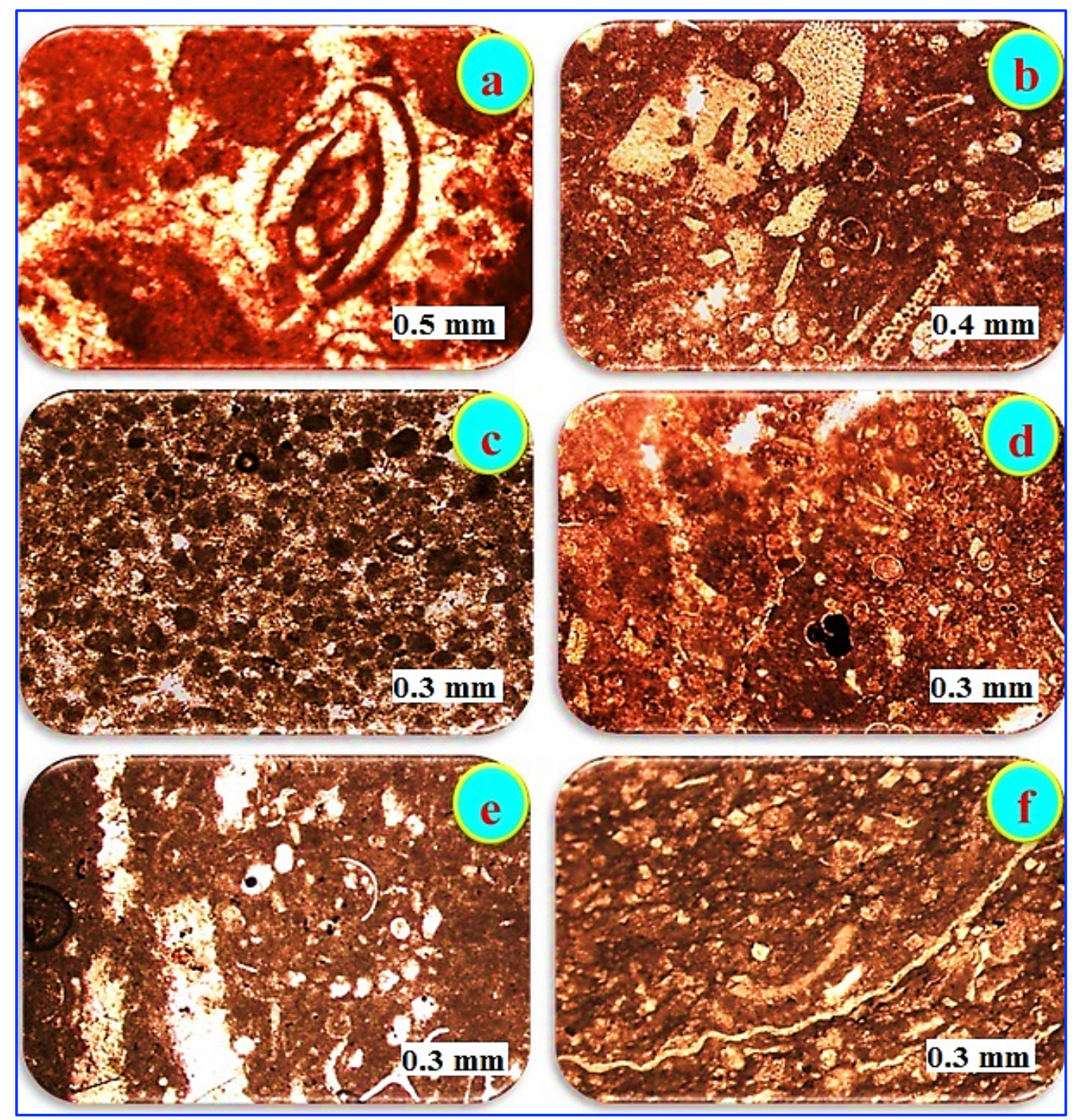

Plate 4. Photomicrographs showing: a) Benthic foraminifera (Lituolidae), algae and peloids within Bioclastic packstone submicrofacies, and also char acterized by micritization, vuggy porosity and micrite cement, Rt-2, depth $2135 \mathrm{~m}$., b) Textularia within Bioclastic packstone submicrofacies, Rt-2, depth 2195m., c) Bioclasts and benthic foraminifera within peloidal packstone submicrofacies, in addition to the presence of vuggy and moldic porosity enhanced by dissolution, Rt-2, depth 2214m., d) Textularia within Bioclastic packstone submicrofacies, and characterized by granular and micrite cement, Rt-2, depth 2192m., e) Benthic foraminifera, Echinoderm, algae and coral fragments within Bioclastic packstone submicrofacies, and, as well as found moldic porosity and the solution channels which appearance associated with stylolite, Rt-5,

2257m., f) Textularia, Miliolidae, coral and algae within Bioclastic packstone submicrofacies, and characterized by dolomitization and micritization with the presence of granular cement and intraparticle porosity and stylolite, Rt-5, depth $2250 \mathrm{~m}$ 


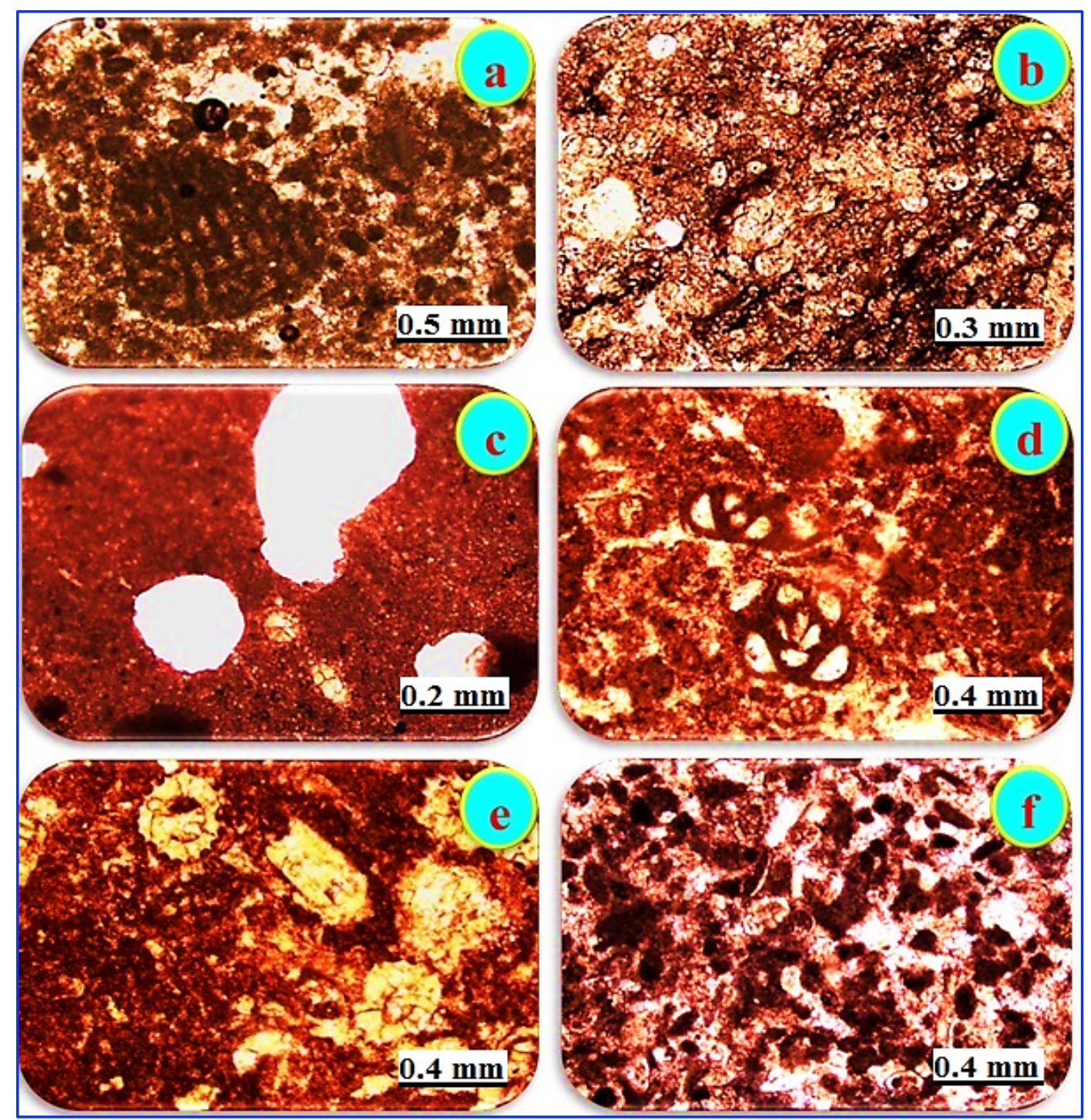

Plate 5. Photomicrographs showing: a) Bioclastic packstone submicrofacies, as well as presence vuggy and moldic porosity, granular and micrite cement, Rt-2, depth 2215m.,

b) Benthic foraminifera (Miliolidae) within Peloidal and Bioclastic packstone submicrofacies, and also presence dissolution and micritization, which represented by the interparticle and moldic porosity, Rt-5, depth 2239m., c) Peloidal and Bioclastic packstone submicrofacies, in addition to micritization, interparticle and moldic porosity and micrite cement, Rt-2, depth $2167 \mathrm{~m}$., d) Textularia, algae, bioclasts and benthic

foraminifera (Valvulinid) within Benthic foraminiferal and Peloidal packstone submicrofacies, and also appearance blocky mosaic and granular cement, Rt-2, depth 2134m., e) Hedbergella, Echinoderm, algae and bioclasts within Benthic foraminiferal packstone submicrofacies, in addition to the presence of blocky mosaic and granular cement, and characterized by micritization, Rt-5, depth 2266m., f) Peloidal packstone submicrofacies and characterized by intraparticle porosity and micrite cement, Rt-2, depth 2137 m 


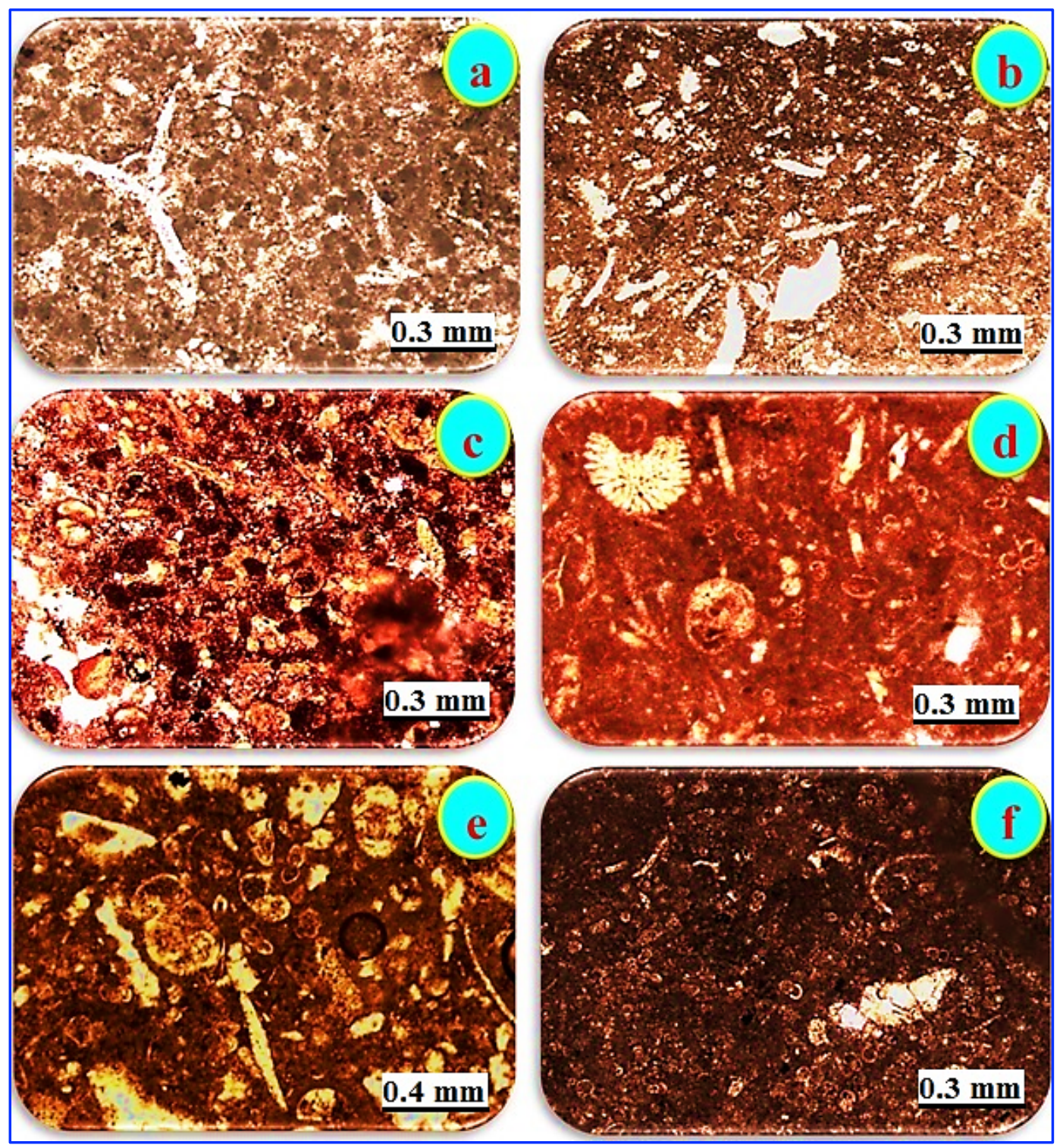

Plate 6. Photomicrographs showing: a) Textularia, coral, algae, bioclasts within Benthic foraminiferal and Peloidal packstone submicrofacies, as well as found recrystallization and micritization with the presence of granular cement and stylolite, Rt-5, depth 2251m., b) Textularia, Cisalveolina, Miliolidae, coral, algae, Echinoderm, bioclasts and rudist fragments within Benthic foraminiferal packstone submicrofacies, and characterized by granular cement, vuggy and moldic porosity, Rt-5, depth $2282 \mathrm{~m}$., c)

Benthic foraminifera (Valvulinid) and bioclasts within Peloidal packstone submicrofacies, and characterized by intraparticle porosity and micrite cement, Rt-2, depth 2136m., d) Bioclastic and benthic foraminiferal within Planktonic foraminiferal packstone submicrofacies, and characterized by vuggy and intraparticle porosity, Rt-2, depth 2193m., e) Bioclasts and benthic foraminiferal and rudist fragments within Planktonic foraminiferal packstone submicrofacies, and characterized by moldic porosity and granular cement, Rt-5, depth $2273 \mathrm{~m}$., f) Hedbergella within Planktonic foraminiferal packstone submicrofacies, as well as found intraparticle and fractured porosity and micrite cement, Rt-2, depth 2163 m 


\section{Diagenetic Processes}

Diagenetic processes are defined as all the physical and chemical changes that occur in sediments before and after the burial process (Flügel, 1982). Dissolution, micritization, cementation, compaction, neomorphism, dolomitization and authigenic minerals are main of diagenetic processes in the Mishrif Formation. The following is a short summary of these operations:

\section{Micritization}

Organic participate in a variety of ways in generation carbonate deposits. After carbonate sediment are deposited, however, organisms may breakdown skeletal grains and other carbonate materials. This organic degradation is actually a kind of sediment-forming process because it results in the production of finer-grained sediment. Nonetheless, it is included here as a type of very early diagenesis because it brings about modification of previously formed sediment. The most important kind of biogenetic modification of sediment is caused by the boring activities of organisms. Boring by using algae, fungi and bacteria is an especially important process for modifying skeletal fabric and carbonate grains (Boggs, 2009). Even greater intensive boring may also result in whole micritization of the grain, with the result that all inner textures are destroyed and a type of peloid is created. This process has been affected widely at the Mishrif Formation in well Rt-2 (Plate 5a).

\section{Dissolution}

The process of dissolving the skeletal and non-skeletal components that exist in the tissue of carbonate rocks due to their mixing with fresh water or may be with seawater (Flügel, 1982). Dissolution depends on the solubility of the minerals; for example, the solubility of calcium carbonate increases from low magnesium calcite (LMC) to aragonite and high magnesium calcite (HMC).

Dissolution generates three types of porosity, namely vuggy, moldic, and intergranular porosity, of which vuggy porosity is the main dissolution type. The formation of vuggy porosity appears to be non-fabric selective (Choquette and Pray, 1970), involving the dissolution of all components (matrix, cement, and grains). The amount of dissolution depends mainly on the length of time that the sediments are exposed to meteoric water. Giles and Marshall (1986) concluded the dissolution process could occur in deep burial environments due to the concentration of $\mathrm{CO}_{2}$, which is produced because of decay, and decomposition of organic materials in clay-rich facies, in addition to the increase of hydrostatic pressure. Dissolution was observed in the Mishrif Formation, where occurred mainly in the bioclastic wackestone microfacies through the dissolving the fossils skeleton 
forming moldic porosity, many basic porosity types recognized in Mishrif Formation according to Choquette and Pray (1970) in Flügel (2004):

1. Interparticle (intergranular) porosity

It is a sort of primary porosity that will occur between the particles during the rocks-genesis. The effect of cementation on this sort of porosity is well observable. Some of the original intergranular porosity is enlarged by later dissolution (Chafeet, 2016). Such porosity types are found in some wackestone and packstone microfacies (Plates 1c, 5b, and 5c).

2.Intraparticle (intragranular) porosity

Its pores similar to described parts of skeletons (intraskeletal porosity, e.g. chambers of foraminifera: Bachrnan 1984 in Flügel, 2004) or to open spaces formed through the removal of much less calcified internal factors (Plates 6d, 5f, 6f, 1a, and 6c).

3.Intercrystalline porosity

Pores between same size crystals often associated with early and late diagenetic recrystallization and dolomitization processes (Flügel, 2004) (Plate 3f).

4.Vuggy porosity

It is pores irregular shape objects and distributed widely, it shows an improvement of reservoir properties and an increase in the permeability ratio due to the continuous connection of the subjected area. It is observed in the Mishrif Formation (Plates $3 \mathrm{~d}$ and $5 \mathrm{a}$ ).

5. Moldic porosity

It includes pores result from the selective removal, typically by using solution, of grains e.g. fossils or ooids. The algae are very sensitive to dissolution. It is significant by geographically wide extend, particular in Mishrif Formation. It is found in the wackestone microfacies (Plates $1 \mathrm{~d}, 2 \mathrm{c}$, and $4 \mathrm{e})$.

6. Fractured porosity

Porosity formed by diagenesis and tectonic movement or collapses a result of solution destruction. It is observed very little in lime mudstone microfacies of the studied area (Plates $1 \mathrm{~d}$ and $1 \mathrm{e})$.

\section{Cementation}

Cementation of the carbonate sediments is an important diagenetic process, which gives strength and stability to the rock. Early diagenetic cement precipitates as fibrous aragonite while granular mosaic cement, drusy and blocky cement precipitate as later diagenetic cements; the later also indicated that these two types of cement could be occurred in deep and shallow environments during late diagenesis processes. It should be noted that all types of cement in the Mishrif Formation are calcareous; silica cement is absent due to water saturated 
in the cavities with seawater that saturated with calcite and aragonite. The cementation is the filling in at essential voids in or of solution cavities by the use of chemically precipitated cements, following kinds of calcite cement were identified at the Mishrif Formation:

1. Equant granular cement

Cement formation is resulted by precipitation from water saturated $\mathrm{CaCo}_{3}$ and nearly from the surface (Dave and Royal, 1999). It is common in wackestone and packstone microfacies (Plates 7a, 7b, 7e, and 6b); crystals of high transparency and small size distinguish this type.

\section{Drusy mosaic cement}

It is characterized by a volume increase from pore wall to the center of the cavities (Flügel, 1982); this type is distinguished by calcite crystals of high transparency and large size with straight flat edges to semi-flat. This kind of cement has a negative impact on the porosity of the formation. It is present in the bioclastic and Algae wackestone submicrofacies (Plates 7d and $7 \mathrm{f}$ ).

\section{Blocky mosaic cement}

Cement formation resulted in continuous sedimentation and increased mechanical pressure because of increased sedimentation load, it is characterized by large size euhedral-subhedral calcite crystals (Flügel, 1982); also, it is precipitated in late diagenesis. It is observed in the studied area (Plates 2d and 7c).

\section{Neomorphism}

This process is regarded as physical origin, which effects in the crystalline form of the rock, without effect in its chemical composition and its effect may be partially or completely (Folk, 1965). Neomorphism process affected some parts of the Mishrif Formation (Plate 1a) both as inversion the aragonite into calcite or converting the calcite to some other calcite that is known as recrystallization, each kind completed throughout re-precipitation and dissolution processes (Longman, 1982).

The Neomorphism can also change the micrite partly or completely to sparite (4-10 microns) or transformed into microsparites, which are less than 4 microns in size and converted to microsparite, which range in size between 30-50 microns, whenever the recrystallization process continues, the microsparite turns into a psuodosparite, which is more than 30 microns in size. In shallow marine environments, the neomorphism process intensifies significantly by using the solution beneath higher temperatures and pressure situations (Flügel, 1982). The intensity in this process is inversely proportional to the ratio of the presence of the muds, whenever the proportions of the muds increase, and the recrystallization process decreased, where the muds impede the recrystallization process (Marschner, 1968). 


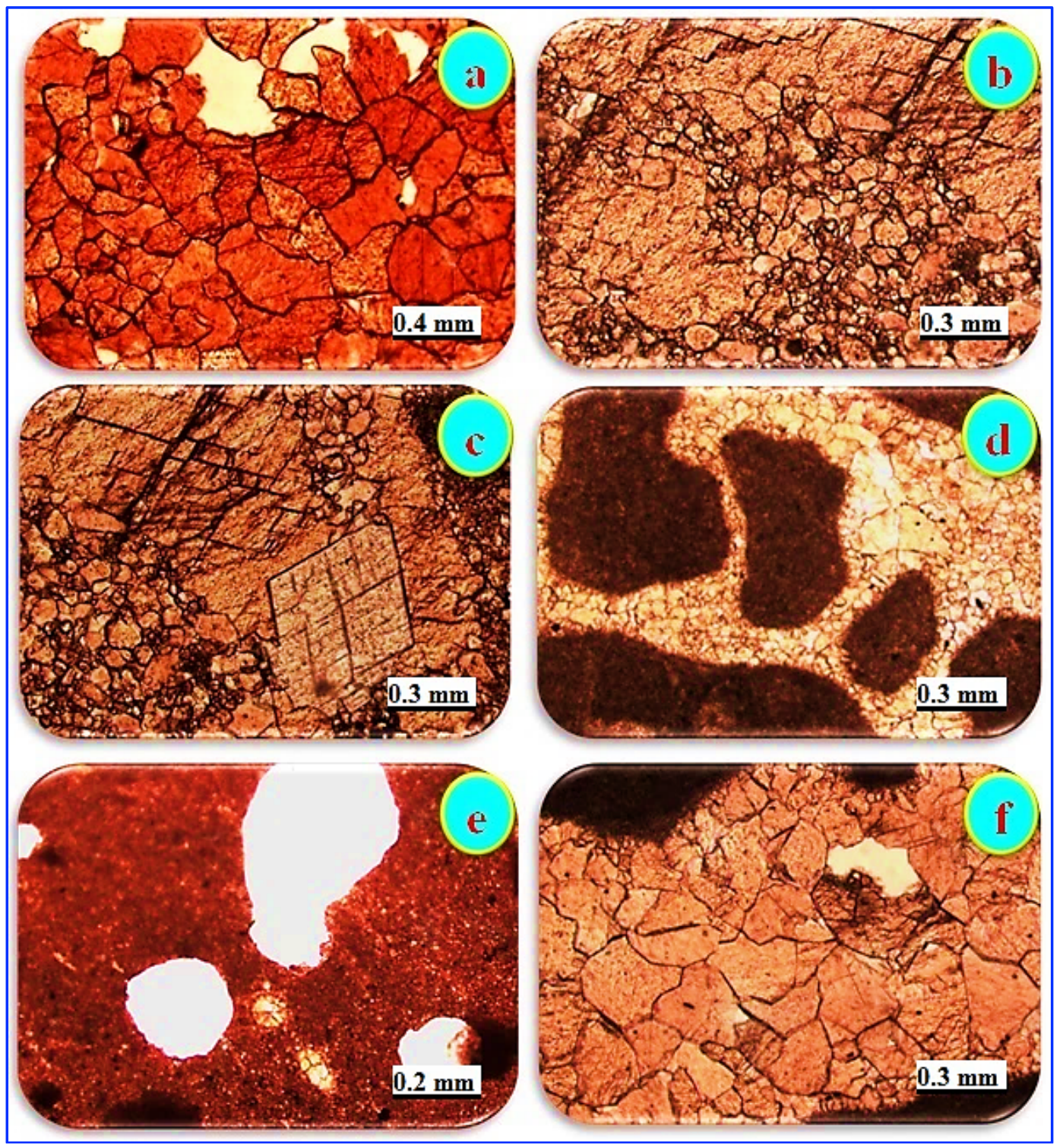

Plate 7. Photomicrographs showing: a) Granular cement, Rt-2, depth 2257m., b)

Granular cement, Rt-2, depth 2140m., c) Blocky mosaic cement, Rt-2, depth 2134m., d) Drusy mosaic, Rt-2, depth $2155 \mathrm{~m}$., e) Granular cement, Rt-2, depth 2167m., f) Drusy mosaic cement, Rt-2, depth $2161 \mathrm{~m}$

\section{Dolomitization}

This is a process through which the dolomite is formed while magnesium ions replace calcium ions in calcite. The early dolomitization occurs by the replacement of precipitated micrite from seawater rich in magnesium ions and contact sediments before their lithification, where calcium ion replaces by magnesium ion that existed in the seawater, or through the mixing of interstitial water between the particles with fresh water after the exposure of sediment to the air, resulting in increased magnesium ion and decreasing of calcium ion, thus dolomite is formed (Xenotopic, Hypidiotopic, and Idiotopic dolomite), this corresponds to the dolomite formed at the dolomitic limestone microfacies in well Rt-5 at the 
Mishrif Formation (Plates 4c and 4f) which reflects the shallow conditions which are formed due to the mixing of the freshwater and marine water observed within the pores of the rocks causing the process of complete dolomitization.

\section{Compaction and pressure solution (Stylolization)}

The compaction regard as one of the latest diagenesis processes of physical origin. In the initial stages, the process of compaction involves the expulsion of liquids that occupy the pores between the grains and therefore reduce the primary porosity of the sediments and the size of the rocks (Plate 3a). There is another type of compaction called compaction of solutions, dissolution of lime materials may occur during or along with grain edges or crystals forming dissolution surfaces (stylolite) which represent the late stage of the diagenetic processes (Friedman 1975), stylolization process occurs after the end of compaction process and the lithification of rocks and as a result of impressing forces on contact surfaces between grains leading to dissolving the calcite mineral which redeposited as cement materials filling the pore space. Stylolite has been observed in some wackestone microfacies in the well Rt-2 (Plates 1a, 3b, 3f, 4e, and, 6a).

\section{Authigenic minerals (Pyrite)}

Authigenic minerals in limestones are generally developed within the form of cubic euhedral crystals. Pyrite is created in normal marine, euxinic and freshwater environments (Flügel, 2004). Pyrite attracts sedimentologists, for the mineral is a valuable indicator of chemical process as presented by (Wilkin et al., 1996 in Flügel, 2004) and diagenesis levels (Hudson, 1992 in Flügel, 2004). Most of the pyrite in sedimentary rocks is of diagenetic origins, although detrital and synsedimentary pyrite occurs, too. Authigenic pyrite commonly forms under reducing conditions replacing organic material or in close proximity to organic material. Pyrite is frequent in the Bioclastic wackestone submicrofacies in the well Rt-2 (Plates 1a and 1b).

\section{Depositional Environment}

It is the overall physical, chemical and biological conditions that impact on sediments. Through the microscopic examination of thin sections, it has been possible to identify sedimentary environments characterized by a number of microfacies accompaniment and then compared with the Standard Wilson Microfacies (SMF) and Facies Zones (FZ) specified by Flügel (2004 and 2010). It can determine the depositional environment as follows:

\section{Sub-basinal environment}

This environment has been observed in the middle and the lower Mishrif Formation, it is represented by planktonic foraminiferal packstone microfacies, which indicating that the 
sedimentation energy is calm and close to the coast, which consists mainly of planktonic foraminifera (Oligostegina, Globotruncana, Hedbergella, and Heterohelix), algae, and peloids with few ratios of both benthic foraminifera (Valvulinid), rudist and peloids. According to the Standard Microfacies (SMF) and Facies Zone (FZ), it is found in the Mishrif Formation similar to SMF-3, which belongs to FZ-3.

\section{Lagoonal environment}

This environment is referred to as deposition in a low energy environment and was observed in the upper, middle and lower Mishrif Formation. This environment is represented by the unfossiliferous lime mudstone, bioclastic lime mudstone, bioclastic wackestone, peloidal wackestone, benthic foraminiferal and peloidal packstone, and peloidal packstone microfacies and it contains bioclast debris represented by of algae, coral, Echinoids, benthic foraminifera (Miliolidae), in addition to the presence of peloids. According to the Standard Microfacies (SMF) and Facies Zone (FZ), it is similar to SMF-19, 23, SMF-19, SMF-18, SMF-16, SMF16, SMF-18, and SMF-3, which belongs to FZ-8, 9, FZ-8, FZ-7, 8, FZ-7, FZ-7, 8, FZ-7, 8, FZ-7, 8, and FZ-3 respectively.

\section{Open shelf margin environment}

This environment has been observed in the middle and lower Mishrif Formation. This environment is represented through the bioclastic wackestone, bioclastic packstone, benthic foraminiferal, peloidal packstone, and peloidal packstone microfacies, it is characterized via the presence of bioclast represented through fragments and particles of algae, coral, mollusca, benthic foraminifera (Valvulinids, Pryozoa, Nezzazata, Cisalveolina, Cycledomia, and Rotalide), planktonic (Textularia), peloids with few ratios of both rudist and Echinoids. According to the Standard Microfacies (SMF) and Facies Zone (FZ), it is similar to SMF-18, SMF-4, SMF-16, and SMF-18, which belongs to FZ-7, 8, FZ-4, FZ-7 and 8.

\section{Shoal environment}

This environment is referred to deposition in high-energy environment within intertidal conditions. This environment has been observed in the middle Mishrif Formation and it is represented only by the benthic foraminiferal and peloidal packstone microfacies. This environment contains bioclasts debris represented by algae and Miliolidae, benthic foraminifera (Valvulinids and Cisalveolina), and peloids. According to the Standard Microfacies (SMF) and Facies Zone (FZ), it is corresponding to SMF-18, which belong to FZ-7, 8. (Figs. 5 and 6) show the proposed depositional environment of the Mishrif Formation in the study area. 


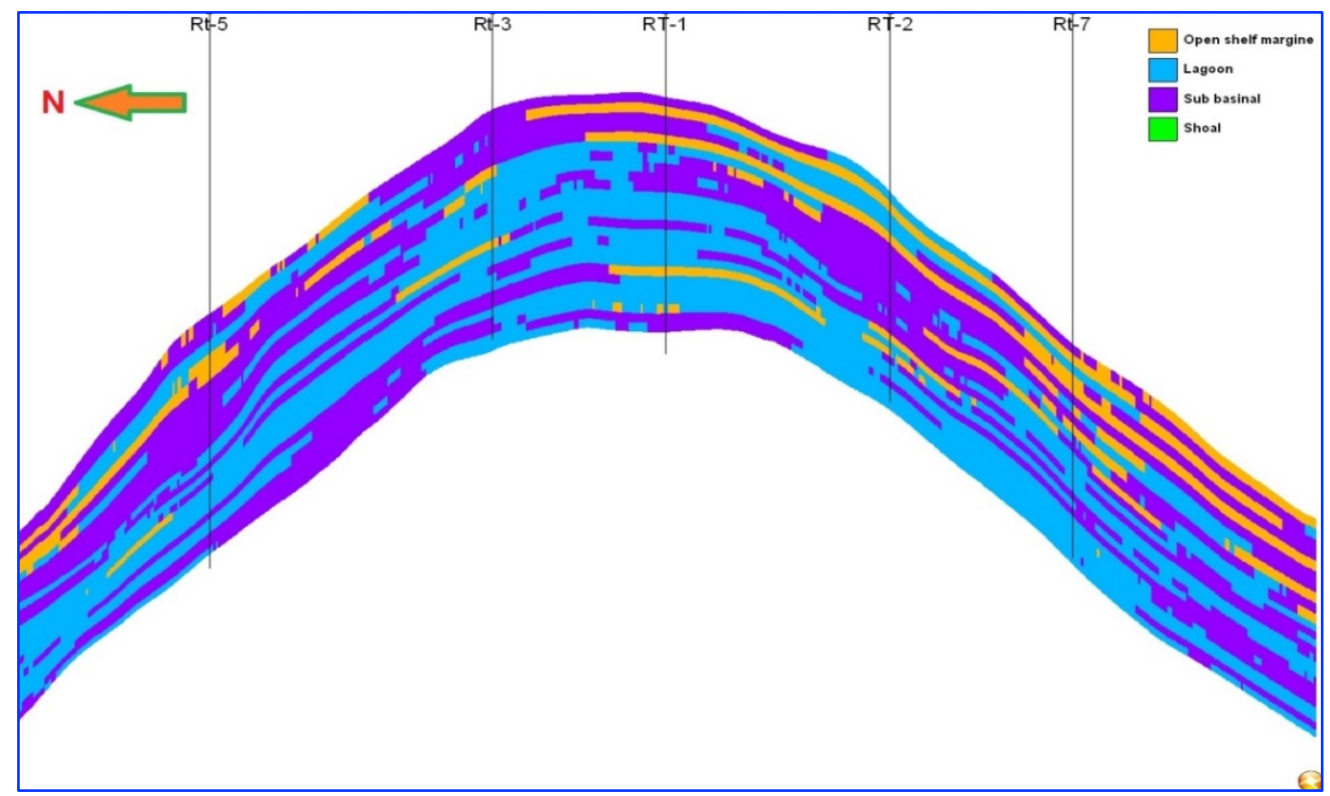

Fig. 5. Longitudinal-section of the depositional environments in the Ratawi oilfield

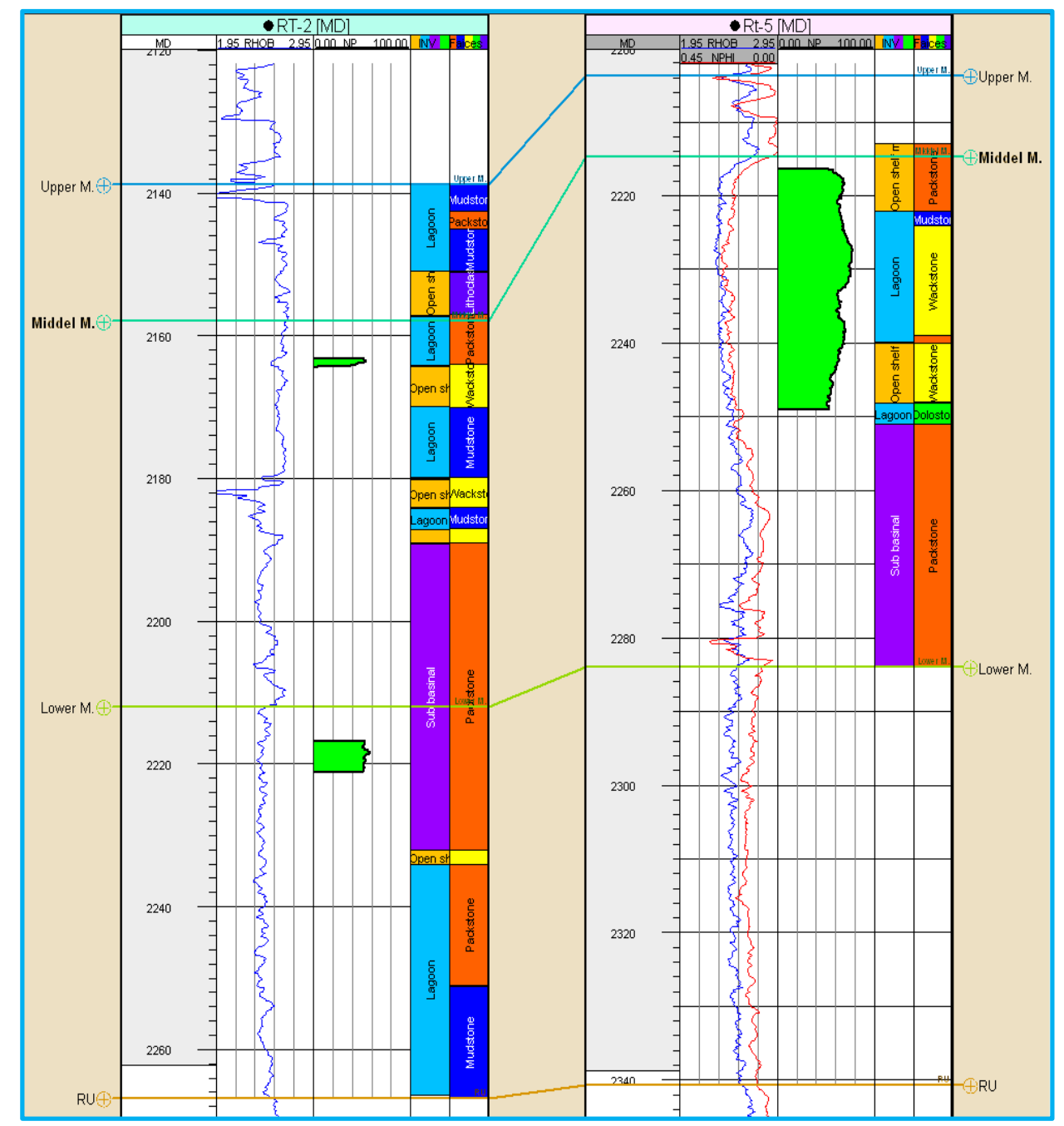

Fig. 6. Facies and depositional environments associations and logs response of Mishrif Formation at studied wells in the Ratawi oilfield 


\section{CONCLUSIONS}

1. The microscopic study of thin sections examinations indicates the existence of seven diagenetic processes in the Mishrif Formation and shows enhanced and destructive effects on the reservoir quality; Dissolution develops the effects through creating and improving porosity and permeability that led to improve the reservoir quality. Cementation, micritization, and compaction have destructive effects, through reducing porosity and permeability that led to reducing reservoir quality. Other processes such as dolomitization, authigenic minerals (pyrite) did not have strong effects on the reservoir quality.

2. Based on genetic classification of porosity, most of porosity within the Mishrif Formation in this field was formed by diagenesis processes, which the predominant pore types are vuggy, intraparticle, fractured, and moldic.

3. The Mishrif Formation is divided into three major microfacies: lime mudstone, wackestone, and packstone, which deposited in sub-basinal, lagoonal, open shelf margin, and shoal environments.

4. Longitudinal-section of the depositional environments showed that the Mishrif Formation deposited in the sub-basinal, lagoonal, open shelf margin, and shoal environments depending on fossils observed in a number of microfacies.

\section{ACKNOWLEDGMENTS}

The authors are very grateful to the Editor in Chief Prof. Dr. Salih M. Awadh, the Secretary of Journal Mr. Samir R. Hijab and the Technical Editor Dr. Heba S. AlMimar for their great efforts and valuable comments.

\section{REFERENCES}

Abbas, L. K. and Mahdi, T. A., 2020. reservoir modeling of Mishrif Formation in Majnoon oilfield, southern Iraq, Iraqi Geological Journal, 53 (1b): 89-101.

Ahr, W. M., 2008. Geology of Carbonate Reservoirs: The Identification. Description and Characterization of Hydrocarbon Reservoirs in Carbonate Rocks. Hoboken, New Jersey. John Wiley \& Sons, Inc., Publication, 296pp.

Al-Ameri, T. K., Al-Khafaji, A. J., and Zumberge, J., 2009. Petroleum system analysis of Mishrif reservoir in the Ratawi, Zubair, North and South Rumaila oil fields, southern Iraq. GeoArabia, 14 (4): 91-108.

Al-Baldawi, B. A., 2020. Determination of pore types and porosity trends using of velocity-deviation log for the carbonate Mishrif Reservoir in Halfaya oilfield, southeast Iraq. Iraqi Geological Journal, 53 (1): 26-37.

Al-Mimar, H. S., Awadh, S. M., Al-Yaseri, A. A. and Yaseen, Z. M., 2018. Sedimentary units-layering system and depositional model of the carbonate Mishrif reservoir in Rumaila oilfield, Southern Iraq. Modeling Earth System and Environment. Springer Nature.

Al-Musawi, F. A., Idan, R.M., Salih, A. L. M. 2019. Reservoir properties and facies distribution of Mishrif Formation in Ratawi oilfield, Southern Iraq. In: Rossetti F. et al., (eds) The structural geology contribution to the Africa-Eurasia Geology: Basement and Reservoir Structure, Ore Mineralisation and Tectonic 
Modelling. Advances in Science, Technology and Innovation (IEREK Interdisciplinary Series for Sustainable Development). Springer, Cham. doi.org/10.1007/978-3-030-01455-1_25

Alsharhan, A.S., 1995. Facies variation, diagenesis, and exploration potential of the Cretaceous rudist-bearing carbonates of the Arabian Gulf. AAPG Bulletin, 79 (4): 531-550.

Aqrawi, A. A. M., 1995. Brackish-water and evaporitic Ca-Mg carbonates in the Holocene lacustrine/deltaic deposits of Southern Mesopotamia. Journal of the Geological Society, 152 (2): 259-68.

Aqrawi, A. A. M., Thehni, G. A., Sherwani, G. H., and Kareem, B. M. A., 1998. Mid-Cretaceous rudist-bearing carbonates of the Mishrif Formation: An important reservoir sequence in the Mesopotamian Basin, Iraq. Journal of Petroleum Geology, 21 (1): 57-82.

Basrah Central Labs, 1974. Geological Study of Mishrif Formation in West Qurna, Well No.1.

Bathurst, R. G. C., 1975. Carbonate Sediment and their diagenesis, $2^{\text {nd }}$ edn. Developments in Sedimentology. Elsevier Scientific Publishing Company, Amsterdam, 12:658pp.

Bellen, R. C. Van, Dunnington, H. V., Wetzel, R. and Morton, D. M., 1959. Lexique stratigraphique international. Asie, Fasc., 10a Iraq. Paris 3:333pp.

Boggs, S. J., 2009. Petrology of Sedimentary Rocks. $2^{\text {nd }}$ Edition. Cambridge University Press, New York. 602pp.

Chafeet, H. A., 2016. Yamama Reservoir Characterization in the West Qurna Oil Field, Southern Iraq. Iraqi Journal of Science, 57(2A): 938-947.

Choquette, P. W., and Pray L. C., 1970. Geologic nomenclature and classification of porosity in sedimentary carbonates. AAPG Bulletin, 54(2): 207-250.

Dave, C. L., and Royal, M., 1999. Microporosity in Arab formation carbonates. Saudi Arabia, GeoArabia, 4(2):129-154.

Dickson, J. A. D., 1966. Carbonate identification and genesis as revealed by staining. Journal of Sedimentary Research, 36 (2): 491-505.

Dunham, R. J., 1962. Classification of carbonate rocks according to depositional texture. In: Ham W.E., Ed., classification of carbonate rocks. AAPG Memoir 1, pp. 108-121.

Flügel, E., 1982. Microfacies Analysis of Limestone. Springer - Verlag, Berlin Heidelberg, New York, 633pp.

Flügel, E., 2004. Microfacies Analysis of Carbonate Rocks: Analysis, Interpretation and Application. Springer Verlag, Berlin Heidelberg, 976pp.

Flügel, E., 2010. Microfacies of Carbonate Rocks: Analysis, Interpretation and Application $2^{\text {nd }}$ edn. Springer Verlag, Berlin Heidelberg, 984pp.

Folk, R. L., 1965. Some aspects of recrystallization in ancient limestone. In: Pray L. C., Murray R. C. Eds., dolomitization and limestone diagenesis, Society for Sedimentary Geology., 13:14-48.

Friedman, G. M., 1975. Society of economic paleontologists and mineralogists; the making and unmaking of limestone or the downs and ups of porosity. Journal of Sedimentary Petrology, 45(2):379-398.

Giles, M. R., and Marshall, J., 1986. Constraints on the development of secondary porosity in the subsurface: Re-evaluation of processes. Marine and petroleum Geology, 3(3):243-255.

Idan, R. M., Salih, A. 1., Al-Khazraji, O. M., Khudhair, M. H., 2020. Depositional environments, facies distribution, and porosity analysis of Yamama Formation in Majnoon oilfield. sequence stratigraphic approach. Iraqi Geological Journal, 53 (1D): 38-52.

Jassim, S. Z. and Goff, J. C., 2006. Geology of Iraq. Published by Dolin, Prague and Moravian Museum, Bron, $341 \mathrm{pp}$.

Kendall, C. G. St., 2007. Sequence Stratigraphy-Introduction, Kendall@ sc.edu. 119pp.

Longman, M. W., 1982. Carbonate diagenesis as a control on stratigraphic traps (with examples from the Williston Basin). AAPG. Education Course Note, 21:159pp.

Marschner, H., 1968. Relationship Between Carbonate Grain Size and Non-Carbonated Content in Carbonate Sedimentary Rocks. In: Muller G., Friedman G.M., $1^{\text {st }}$ edn. Recent Development in Carbonate Sedimentology in Central Europe. Springer - Verlag, Berlin, pp. 55-58.

Mohammed A. K., Radhi, J. K., and Ali, S. Z., 2020. Well logs data prediction of the Nahr umr and Mishrif formations in the well Noor-10, southern Iraq. Iraqi Geological Journal, 53 (2a): 50- 67.

Wilson, J. L., 1975. Carbonate Facies in Geologic History. Springer - Verlag, New York, 471pp. 